\title{
The Mode and Function of Enterprise Assets Reorganization in
}

\author{
China \\ Xiao-Fang Wang ${ }^{\text {a }}$, Dong-Dong Weng ${ }^{b^{*}}$ \\ ${ }^{a}$ Liming Vocational University, Fujian, Quanzhou, China \\ ${ }^{\mathrm{b}}$ Quanzhou Normal University, Fujian, Quanzhou, China \\ *Corresponding author: Dong-Dong Weng, undergraduate, weng28911985@163.com
}

\begin{abstract}
At present, with the vigorous development market economy in China, the pressure of market competition is also growing, the increasing competition in the context of China's enterprises, acquisitions, division, merger, transfer of assets restructuring mode emerge in endlessly, the assets of the enterprise restructuring can quickly and effectively improve the management ability of enterprise, the degree of flexibility and adaptability, can bring new competitive advantage, is helpful to development of market economy, promote the management synergy between enterprises.

Enterprise asset restructuring are discussed in this paper, understanding the problems of asset reorganization, this paper try to express an opinion about the purpose and function of our country enterprise assets reorganization.
\end{abstract}

Key words: the listed company; assets reorganization; related party transactions

\section{Overview of the reorganization of assets}

\subsection{Content asset restructuring}

Asset restructuring generally refers to the enterprise in order to transform the original assets into other USES of assets, and a kind of economic activity, the purpose is to enterprises to better development, not be abandoned by time. In specific operations, assets reorganization including enterprise mergers and acquisitions, asset replacement, divestitures, equity transfer, etc.

\subsection{Necessity of enterprise assets restructuring}

Large number of enterprises, and most of them are relatively small size of the economy, is still in the start-up phase of the enterprise, the enterprise's overall capital and overall strength are low, which has a relatively weak competitiveness, which is the current situation of many companies . On the other hand, Chinese enterprises have a number of Western countries and a significantly less contrast, which indicates that Chinese enterprises have great room for development, it is still very potential of its development. Through reorganization of assets, many of our businesses to enable enterprises to more competitive and development space, enabling enterprises more responsive to development needs of the times, but also enable 
enterprises to adapt to the survival of the fittest under the existing economic system and social development needs, to further stimulate enterprise development potential. By supporting the development of enterprises, it has a certain degree of competitiveness in the social economy, and then change the previous corporate debt single, abstract problems. In recent years, China's economic growth mode from delicate to intensive change, which also further promote the enterprise speed up the transformation. ${ }^{1}$ In China, if you want better business development changes, we must take the appropriate solutions, corporate recapitalization scheme will develop with it. At the same time, the development of accounting in a business essential, so Chinese enterprises should pay attention to the reorganization of assets as they relate to accounting management problems, allows companies become rapid and healthy development.

\section{Mode of enterprise assets restructuring and purpose}

\subsection{Way of asset restructuring of SMEs}

China's current situation is not the same as the development of SMEs, and the current market environment is also changing. Therefore, along with the way the reorganization of assets is also changing, and there is no fixed way. Last few years, considering the various places in the government, enterprises and individual workers of various capacities, thus actively explore various features in line with the SMEs. At the same time all parts of the enterprise organization and management of a lot of work to create content experience and proven methodologies were a large number of asset restructuring.

\subsection{1 mergers and acquisitions}

In China, mergers and acquisitions under certain conditions of system and enterprise system of property rights, transfer of property rights by enterprises during payment of other companies registered enterprises or enterprise groups in the acquisition of this enterprise. For some enterprises through the transfer of property to another business and obtain the corresponding interests and other aspects of business mergers and acquisitions to achieve the purpose of the control of these property rights. Enterprises through mergers and acquisitions of other companies in certain funds and the corresponding number of properties, the combined company will lose the original control and management rights. ${ }^{2}$

\subsubsection{Equity Transfer}

The transfer of shares in the reorganization of assets in the common way, because it is a very effective way of asset restructuring of many companies, enabling enterprises to quickly be transformed. Equity transfer in China is mainly refers to the way the class of stock transfer, acquired, through the transfer of equity shares of the enterprises has been changed, the pattern has been changing, thereby facilitating interaction and rational allocation of corporate resources. 


\subsubsection{Asset Swap}

Replacement of assets as an important market profit model, in order to achieve high-quality assets and capital structure of listed companies and large shareholders adjustment mode. Changes in tradable shares, the asset replacement process itself, there have been many new forms. ${ }^{3}$ For example, the private placement of new shares has not only become an important tool for equity refinancing of listed companies,but also become a growing asset replacement payment.

\subsubsection{Divestiture}

Divestiture is a characteristic belonging to shrink capital activities. This mainly refers to the listed companies will transfer their assets to the target company in order to change the operating status of the company and the behavior plays a key role in optimizing the allocation of corporate resources. Divestment by enterprises more and more attention, their number and size scale is an increasingly clear upward trend, enterprise assets restructuring activities have a major impact. The reason listed company divestiture, is to give up some contact with the company's core business and less closely to long-term development strategy, a certain lack of growth potential of the business and assets of the business by changing the way the business focused on core business in the long run it is a good strategic decision for the company's growth and development, for the company to create long-term wealth plays an important role.

\subsubsection{Other}

To sum up is our basic asset restructuring, the majority of our small and medium enterprises have adopted over the several ways the reorganization of assets, but because of the way of asset restructuring is not fixed in stone, there will be other asset restructuring such as:debt restructuring of state-owned shares repurchased, hosting, company spin-off, rental belong to other asset restructuring the way, SMEs in China during the reorganization of assets restructuring is often selected is the most suitable enterprise itself, so few companies It will be used in this way the reorganization of assets, making itself more competitive and development force. $^{4}$

\subsection{Objective of enterprise assets restructuring}

In order to better adapt to the economic reforms in order to better enable enterprises to maximize efficiency when carrying out our corporate reorganization of assets, it has its corresponding particular purpose. China's economy in constant development, in order to make their own be able to obtain greater economic benefits, get more benefits, while most enterprises in the reorganization of assets, in addition to the general motivation asset restructuring, which has more or less corresponding special purpose, so that the enterprises to better adapt to the trend of economic reform. 


\subsubsection{Financing purposes}

This approach enables the financing of enterprises to obtain funds in the development process, which can maintain the normal operation of enterprises, thus contributing to long-term development.China's enterprises in their own development process, due to the lack of financing,coupled with the corporate shareholding structure special properties, such enterprises in equity financing when financing becomes a cheap mode. But while the situation is grim, companies still have to solve their own development problems. As the saying goes, not how the funds operate, no funds means that companies may not be able to stay in business, they may face the risk of bankruptcy, closure. Therefore, SMEs reorganization of assets, the correct full financing seem important.

\subsubsection{Control revenue goals}

Enterprises in the process of asset restructuring in order to realize a profit on the income distribution as much as possible strive for the greater good, do it so you can control corporate earnings. In some enterprises have a strong control over major shareholders, often occur between this case and other shareholders the distribution of benefits conflicts, which is distributed among the shareholders equity on a prominent problem. At this time, the major shareholder can control your own personal interests, or exceed their holdings of cash flow rights for additional income, and this is the major shareholder of additional revenue through a variety of ways to infringe on the interests of other shareholders acquired.And this phenomenon in our country market economy is a relatively phenomenon. At present, listed companies ownership concentration are high, control of the business is relatively large. Thus when the company conducting the elections, major shareholders in their own interests often will elect their trust into the corporate management, to achieve greater control of the enterprise.Therefore, control proceeds SMEs also one of the special purpose asset restructuring. ${ }^{5}$

\subsubsection{Resource sharing and increasing the value of the target}

To promote the sharing of resources of the enterprise resource convenient, efficient and rational use, reducing the time-consuming and unnecessary enterprise in operation and management, greatly improving efficiency. Our modern enterprise group should be further strengthened awareness of resource sharing, and gradually realize the sharing of resources, modernization.At the same time the need to establish an effective asset management approach, the existing funds and assets for effective use, the ability to increase the preservation of assets. The financial and accounting work was added to the asset management process, the asset restructuring enterprises play a key role. This is an important way to improve the operational efficiency of assets, and improving overall efficiency. 


\section{The role of asset restructuring company}

\subsection{Enable enterprises to improve efficiency and market share}

Under the market economy system, the ultimate goal of any business is to expand the business scope, business scale, improve profitability and expand market share, in order to achieve maximum benefit. At the same time, asset restructuring and the strength to make the more powerful enterprise annexation disadvantaged businesses, large enterprises mergers and acquisitions of small businesses, or a plurality of two companies joined forces to achieve the integration of resources, assets, in order to achieve the set of inter-enterprise assets, complementary strengths and resources, mutual cooperation, optimize resources elemental structure. Once assets have greater financial strength, companies can have capital to expand production scale, to obtain economies of scale, synergy under the new technical conditions. At the same time the reorganization of assets is also possible to reduce competition in the market, to enhance market share of joint ventures, companies can achieve some degree of monopoly in such a competitive advantage, not only to obtain monopoly profits, but also to maintain a strong competitive advantage, thereby realization of long-term profits earned.

\subsection{To promote the optimization and adjustment of the economic structure of the enterprise}

Enterprises in order to quickly develop, we must address the reorganization of assets this trend exists, adjust to change the traditional economic structure. Stage offset the economic structure will exist in the process of economic globalization, which directly affect the healthy and sustainable development of the market economy enterprises. Reorganization of assets for enterprises in the changes in the economic structure of an active role in promoting its role is mainly reflected in:the first is the enterprise to obtain incremental funding, the lack of incremental funding transferred to the field or area, so that enterprises in the allocation of financial resources, industrial structure It tends to be reasonable and so on, so that enterprises can be healthy and sustainable development; the second is to adjust the optimal allocation of the company's existing stock of assets, making it circulate, the adjustment of economic structure.

\subsection{Helping to spread the risk, diversify, get rid of delisting crisis}

Single business industry, business enterprises are faced with a narrow range of fluctuation of the market economy may suffer a fatal blow. As the market economy can not be controlled, even though the situation there will correctly predict the unknown, changing a single enterprise property rights can allow enterprises to get more economic benefits, asset restructuring of enterprises can achieve this goal. ${ }^{6}$ Enterprises through asset restructuring the business, the business scope expanded, stretched out to other industries outside the company's existing business, such diversification will not only improve the level of corporate profits, but also can prevent economic fluctuations caused by the collapse of a particular area companies were eliminated, companies can go to get the mainstay of the economy from 
another area. Reorganization of assets allows companies to have a more flexible approach to adapt to changes in the market, helping enterprises to enter new business areas and emerging markets After the asset restructuring companies can get plenty of money and richer management, and for enterprises to expand production scale and reduce the cost of doing business, competition for market share is helpful, but also allows companies to feel at ease innovation to find new profit growth point.

\section{Conclusions}

Reorganization of assets can help enterprises to expand in a highly competitive market environment scale,improve efficiency and increase market share and promote the optimization and adjustment of the economic structure of the enterprise, helping to spread the risk, diversify, get rid of delisting crisis, it is to get rid of the enterprise capital and management dilemma for bone reincarnation of an important way. And because of China's capital market and financial system of relevant laws and regulations immature, resulting in unfair and prone to various accounting issues in asset restructuring process. Intermediaries imperfect; corporate funds are big shareholders chaos occupancy; information disclosure is not standardized; allow listed companies to achieve the purpose for which the loan guarantee of behavior makes the company faced enormous market operators operating and financial risks. The focus of this analysis is the problem, accounting for asset restructuring can objectively reflect the problems, but can not detect all the problems, but how to solve these problems still need to investigate the long-term practice to complete.

\section{References}

1. Y.Yuan, Listing Corporation's assets restructuring and accounting supervision innovation [J]. accounting and finance, 2011, No.53624:17-19.

2. C. Zhang, The purpose of the enterprise assets reorganization and the analysis of the existing problems of the [J]. business modernization, 2014 (22)

3. H.Chen, W.Chen, Research on the accounting problems of enterprise assets reorganization [J]. enterprise accounting, 2015 (4)

4. X.Han, Research on the accounting of asset reorganization [J]. modern business, 2014 (3)

5. Y. Shi, Analysis of the accounting problems in asset reorganization of listing Corporation [J]. modernization of shopping malls, 2015 (1)

6. Y.Song, Research on accounting problems of asset reorganization [J]. accounting research, 2015 (11) 